\title{
Chemical composition of grains and environmental efficiency in soybeans grown under low latitude conditions
}

\section{Composição química dos grãos e eficiência ambiental em soja cultivada sob baixa latitude}

\section{Douglas José DARONCH ${ }^{1}$; Joênes Mucci PELUZIO²; Flavio Sergio AFFERRI ${ }^{3}$; Aline Torquato TAVARES ${ }^{4}$; Clovis Maurílio de SOUZA ${ }^{5}$}

\author{
${ }^{1}$ Doutor em Produção Vegetal, Instituto Federal do Tocantins, campus avançado Formoso do Araguaia; \\ douglasdaronch@hotmail.com \\ ${ }^{2}$ Doutor em Genética e Melhoramento; Universidade Federal do Tocantins; joenesp@uft.ed.br \\ ${ }^{3}$ Doutor em Agronomia; Universidade Federal de São Carloas; flavio@uft.edu.br \\ ${ }^{4}$ Autor para correspondência; Pesquisadora PNPD CAPES no Programa de Pós-Graduação em Produção Vegetal; \\ Universidade Federal do Tocantis, Departamento de Agronomia - Rua Badejós, Lote 7, Chácaras 69/72, Zona Rural. Cx \\ Postal 66. CEP: 77402-970, Campus de Gurupi -TO; alinet4t@hotmail.com \\ ${ }^{5}$ Doutor em Agronomia; Universidade Federal do Tocantins; clovis@uft.edu.br
}

Recebido em: 12-09-2017; Aceito em: 25-07-2018

\begin{abstract}
Soybeans are one of the main commodities in Brazil, with soybean oil and meal used as raw material for food and animal feed production. However, information on the chemical characteristics of soybeans produced at different times of the year and on the efficiency of genotypes under low latitude conditions is scarce. This study evaluates the environmental efficiency of soybean genotypes based on oil and protein contents during in-season and offseason periods, in Tocantins State. The experimental design was a randomized block with seventeen treatments (genotypes) and three replicates. The treatments were composed by cultivars TMG 1288 RR; AS 3810 IPRO; CD 2792 RR; CD 251RR; CD 2737RR; SHS 820 IPRO; TMG 1180 RR; M 8766 RR; P 98Y70RR; M 9144 RR and strains 5X6-1; 5X6-2; 5X6-3; 4X6-12; 4X6-17; 4X6-19 and 4X5-2. There was effect of sowing times on the oil and protein contents of the grains. Genotype TMG 1288 RR presented the highest levels of oil and protein. The best sowing time for protein content was the first of the in-season (12/01). For oil content, in turn, the off-season stood out (06/01), evidencing that early sowing resulted in better results. Since the contents of these two elements are inversely proportional, one must verify the desired purpose to choose the material to be used. The identification of superior genotypes by the proposed index was effective only for unfavorable environments.
\end{abstract}

Additional keywords: oil content; protein; sowing times; soybean hybrids.

\begin{abstract}
Resumo
A soja, uma das principais commodities do Brasil, tem o óleo e o farelo como matéria-prima para a produção de alimentos e ração animal. Entretanto, são escassas as informações sobre as características químicas dos grãos de soja produzidos em diferentes épocas do ano, bem como a eficiência de genótipos em condições de baixa latitude. O presente trabalho teve como objetivo avaliar a eficiência ambiental de genótipos de soja, com base nos teores de óleo e proteína, nos períodos de safra e entressafra no Estado do Tocantins. O delineamento experimental utilizado foi o de blocos casualizados, com dezessete tratamentos (genótipos) e três repetições. Os tratamentos foram constituídos pelas cultivares TMG 1288 RR; AS 3810 IPRO; CD 2792 RR; CD 251RR; CD 2737RR; SHS 820 IPRO; TMG 1180 RR; M 8766 RR; P 98Y70RR; M 9144 RR e pelas linhagens 5X6-1; 5X6-2; 5X6-3; 4X6-12; 4X6-17; 4X6-19 e 4X5-2. Houve efeito das épocas de plantio nos teores de óleo e proteína nos grãos. O genótipo TMG 1288 RR apresentou os maiores teores de óleo e proteína. A melhor época de semeadura para teor de proteína foi a primeira safra (01/12), já para o teor de óleo foi na entressafra $(01 / 06)$, evidenciando que a antecipação da semeadura proporcionou melhores resultados. Como os teores desses dois elementos são inversamente proporcionais, deve-se verificar a finalidade desejada para poder escolher o material a ser utilizado. A identificação dos genótipos superiores pelo índice proposto foi eficaz apenas para ambientes desfavoráveis.
\end{abstract}

Palavras-chave adicionais: épocas de semeadura; híbridos de soja; proteína; teor de óleo.

Introduction

Among the states with agricultural aptitude in the Cerrado biome, Tocantins emerges as one of the most promising, due to land availability and the logistics of distribution (Peluzio et al., 2010). In this state, soybean is the third crop in terms of participation in the gross value of production. In the off-season (May- 
June), it is cultivated in irrigated lowland, under subirrigation (groundwater elevation), mainly in Formoso do Araguaia. In the in-season (November-December), in turn, cultivation takes place in upland conditions (Martins et al., 2015). The product is of major importance in the Brazilian economy, occupying a prominent place in the supply of oil for domestic consumption, in animal feed (as the main source of protein), and in the country's export agenda (Castro et al., 2015).

The soybean grain contains approximately $20 \%$ of oil, $38 \%$ of protein and $34 \%$ of carbohydrates, as well as fibers and inorganic constituents, whose composition varies according to genetics and environmental conditions, from 20 to 40 days before grain maturation (Embrapa, 2010; Sbardelotto \& Leandro, 2008).

Regarding sowing times, in soybean cultivars, higher temperatures and lower average rainfall during the grain-filling stage favored oil accumulation in the grains (Barbosa et al., 2011). There is a positive correlation between oil content and yield, being possible to maintain yield when the selection for high oil content is practiced (Rodrigues et al., 2013).

With early sowing of soybean in Paraná State, there was an increase in oil content and a reduction in protein content in grains (Albrecht et al., 2008). These results characterize the negative correlation between oil and protein contents in the chemical composition of the grains, due to the competition of these two strands by carbon skeletons (Finoto et al., 2017).

Since the chemical composition of grains is dependent on environmental conditions, the choice of the cultivar according to sowing time, region and management strategies adopted is of paramount importance to obtain profitable yields, especially when combined with the understanding of the limitations and/or advantages of the production environment (Peluzio et al., 2008).

In view of the above, this study evaluates the environmental efficiency of soybean genotypes based on oil and protein contents during in-season and offseason periods, in Tocantins State.

\section{Material and methods}

Four competition trials of soybean cultivars were carried out in the agricultural year 2013/14. Two of these trials were installed under Cerrado conditions in Palmas City, Tocantins State, at the Agrotechnology Center (10 $45^{\prime} \mathrm{S}$ and $47^{\circ} 14^{\prime} \mathrm{W}$, at $220 \mathrm{~m}$ altitude). These first experiments were held on December 01 and 17, 2013 (in-season - rainy period), which is a period traditionally used for sowing aimed at grain production. The other two experiments were conducted in the Experimental Field of Gurupi ( $1^{\circ} 43^{\prime} 5^{\prime \prime} \mathrm{S}$ and $49^{\circ} 04^{\prime} \mathrm{W}$, at $280 \mathrm{~m}$ altitude), on June 01 and 17, 2014 (off-season, dry period), a period traditionally used for sowing aimed at seed production. Each sowing time represented a distinct environment. The soil where the trials were performed are classified as Dystrophic RedYellow Latosol.

The experimental design used in each trial was randomized blocks with 17 treatments (genotypes) and three replicates. The treatments were composed by cultivars TMG 1288 RR; AS 3810 IPRO; CD 2792 RR; CD 251RR; CD 2737RR; SHS 820 IPRO; TMG 1180 RR; M 8766 RR; P 98Y70RR; M 9144 RR and strains 5X6-1; 5X6-2; 5X6-3; 4X6-12; 4X6-17; 4X6-19 and $4 \times 5-2$, developed by the genetic breeding program of UFT.

The experimental plot, in each trial, was composed of four 5-m long rows, spaced $0.45 \mathrm{~m}$ apart. At harvest, the two central rows were used, discarding $0.50 \mathrm{~m}$ from the end of each row, resulting in a plot area of $3.6 \mathrm{~m}^{2}$.

Plowing, harrowing and furrowing were performed in each trial. Sowing and furrow fertilization were done manually. Sowing fertilization was performed according to soil analysis (Table 1) and the recommendation for the crop. In addition, cover fertilization was performed at 15 days post-emergence, quantifying a total of $100 \mathrm{~kg} \mathrm{ha}^{-1} \mathrm{~K}_{2} \mathrm{O}$.

Table 1 - Soil chemical analysis carried out in the two years of the experiments.

\begin{tabular}{cccccccc}
\hline Year & $\begin{array}{c}\mathrm{P} \\
\left(\mathrm{mg} \mathrm{dm}^{-3}\right)\end{array}$ & $\begin{array}{c}\mathrm{K} \\
\left(\mathrm{cmol}_{\mathrm{c} \mathrm{dm}}{ }^{-3}\right)\end{array}$ & $\begin{array}{c}\mathrm{Ca}+\mathrm{Mg} \\
\left(\mathrm{cmolc}_{\mathrm{cm}}^{-3}\right)\end{array}$ & $\begin{array}{c}\mathrm{Al}+\mathrm{H} \\
\left(\mathrm{cmol}_{\mathrm{cm}} \mathrm{dm}^{-3}\right)\end{array}$ & $\begin{array}{c}\mathrm{pH} \\
\left(\mathrm{CaCl}_{2}\right)\end{array}$ & $\mathrm{V} \%$ & $\begin{array}{c}\mathrm{MO} \\
\left(\mathrm{g} \mathrm{dm}^{-3}\right)\end{array}$ \\
\hline 2013 & 10.4 & 0.13 & 2.3 & 2.3 & 5.2 & 51.6 & 20 \\
2014 & 11.1 & 0.15 & 2.4 & 1.9 & 5.1 & 59.6 & 21 \\
\hline
\end{tabular}

At sowing, seeds were treated with fungicides, followed by inoculation with Bradyrhizobium japonicum strains. Seed density was determined so as to obtain 14 plants per linear meter. Pest, disease and weed control were performed as needed. In the sowings made in Gurupi (off-season), due to rainfall scarcity, sprinkler irrigations were carried out whenever necessary.

The plants from each experimental plot were collected after presenting $95 \%$ mature pods, that is, at stage $R_{8}$ (Fehr et al., 1971). The grains had a moisture content of $18 \%$, on a wet basis, obtained by indirect method based on the dielectric properties of grains through GEHAKA equipment. Subsequently, 25 to 30 grams of whole grains were placed in an oven at $130{ }^{\circ} \mathrm{C}$ for a period of 16 hours until the moisture content reached around $13 \%$.

Afterwards, three samples containing $100 \mathrm{~g}$ of the grains of each plot were separated, and the oil content of the grains (\%) was determined in the 
Laboratory of the Food Engineering Course of the Federal University of Tocantins - Palmas Campus, using the Soxhlet method (Instituto Adolfo Lutz, 1985). Protein content was determined using the Kjeldahl method, based on the quantification of total nitrogen, as recommended by AOAC (1975).

For each genotype, using the values of oil and protein content from the four trials (environments), an environmental efficiency index (EEI) was obtained. For this, initially, favorable and unfavorable environments were defined, according to Finlay \& Wilkinson (1963). These authors state that favorable environment is one whose average of a given test (environment) is above the general average of all tests, resulting in a positive environmental index. On the other hand, unfavorable environment is one whose average of a given test is below the general average of all tests, resulting in a negative environmental index.

From the definition of the environments, the environmental efficiency index (EEI) was obtained, according to the methodology adapted from Fischer et al. (1983), by the following expression:

$E E I=\frac{Y a(U)}{Y a(F)} \times \frac{Y x(U)}{Y x(F)}$

Wherein: EEl is the environmental efficiency index;
$\mathrm{Ya}(\mathrm{U})$ is the yield of genotype "a" in environment $U$ ("unfavorable"); $\mathrm{Ya}(\mathrm{F})$ is the yield of genotype "a" in environment $F$ ("favorable"); Yx (U) is the average yield of all genotypes in environment $U ; Y x(F)$ is the average yield of all genotypes in environment $F$.

EEl is used to classify cultivars as efficient (index above the general average) and non-efficient (index below the general average), since the means of cultivars in $\mathrm{F}$ and $\mathrm{U}$ environments are used.

We performed an analysis of variance of each trial and, later, a joint analysis of the trials in which the lowest residual mean square did not differ by more than seven times the highest one (Cruz et al., 2004). The means were compared by the Scott Knott test, at the $5 \%$ significance level.

Statistical analyses were performed using the GENES software, version 2007 (Cruz, 2007).

\section{Results and discussion}

Joint analysis of variance (Table 2) detected a significant effect for sowing time and the interaction cultivar $x$ sowing time for all traits. The effect found for the interaction indicates that the isolated effects of cultivars and times did not explain all the variation found. Thus, unfolding was performed.

Table 2 - Summary of the analysis of variance of two agronomic traits evaluated in 17 soybean genotypes, in the $2013 / 14$ crop, in the central-south region of the state of Tocantins.

\begin{tabular}{lrcc}
\hline \multirow{2}{*}{ Causes of variation } & \multirow{2}{*}{ FD } & \multicolumn{2}{c}{ Mean square } \\
\cline { 3 - 4 } & & Oil content & Protein content \\
\hline Cultivar & 16 & $15.43 \mathrm{~ns}$ & $41.97 \mathrm{~ns}$ \\
Time & 3 & $240.69^{*}$ & $21.89^{*}$ \\
Cultivar x Time & 48 & $26.32^{*}$ & $28.50^{*}$ \\
Block/Time & 8 & 2.69 & 4.11 \\
Error & 128 & 2.11 & 4.44 \\
Total & 203 & & 6.32 \\
\hline CV $(\%)$ & & 7.34 & 33.29 \\
Mean & & 19.79 & \\
\hline
\end{tabular}

Oil content (\%); Protein content (\%); ns: no significant; * significant by the F test $(p<0.05)$.

The oil content of soybean genotypes in the four sowing times is presented in (Table 3), as well as the definition of favorable and unfavorable environments. In the first sowing time (12/01) in Palmas, five groups of statistically distinct means were formed. Genotypes SHS 820 IPRO (24\%), CD 2792 RR $(21.5 \%)$ and CD 2737 RR $(21 \%)$ showed the highest oil contents, while 5X6-3 (13.5\%) showed the lowest value for this variable. The other genotypes were found in statistically intermediate groups.

In the second sowing time (12/17) in Palmas, three groups of means were formed. The group with the highest oil content was represented by M 8766 RR, 4X5-2, 5X6-3 and 5X6-2, with 23.5; 23.0; 23.0 and $22.8 \%$, respectively. Genotypes CD 2737 RR, SHS 820 IPRO and TMG 1180 RR are also highlighted, both with $21 \%$ oil in the grains, above the mean value of around $19.5 \%$. The lowest oil content was obtained by AS 3810 IPRO (16.0\%), although it did not differ statistically from TMG $1288 \mathrm{RR}, \mathrm{CD} 2792 \mathrm{RR}, \mathrm{CD}$ 251RR, 4X6-12, 4X6-19, 5X6-1, 4X6-17, P 98Y70RR and M 9144 RR. This percentage is influenced by the environment and cultural practices.

The comparative study between genotypes in the two sowing times in Palmas revealed inconsistency of the results, in which some genotypes showed behavioral similarity between times, while others showed a higher oil content in the second sowing (12/17). This behavioral similarity was probably due to the good distribution of rainfall during the grain-filling period in the two sowing times, along with the occurrence of temperatures above $25 \stackrel{\circ}{\circ}$ (Figure 1), which favors oil accumulation in the grains.

These results agree with those obtained by Sediyama et al. (1996), who verified that in the grainfilling stage, under $21^{\circ} \mathrm{C}$, the oil content was $19.5 \%$, while at temperatures above $30^{\circ} \mathrm{C}$, the oil content in the grains was $22.3 \%$. 
Table 3 - Oil content in percentage, in the seeds of seventeen soybean genotypes, produced in four sowing seasons, in the 2013/14 crop, in Palmas and Gurupi-TO and the definition of environments proposed by Finlay \& Wilkinson (1963).

\begin{tabular}{|c|c|c|c|c|c|}
\hline \multirow{3}{*}{ Genotype } & \multicolumn{4}{|c|}{ Oil content (\%) } & \multirow{3}{*}{ Mear } \\
\hline & \multicolumn{2}{|c|}{ Sowing time - Palmas } & \multicolumn{2}{|c|}{ Sowing time - Gurupi } & \\
\hline & $12 / 01 / 2013$ & $12 / 17 / 2013$ & $06 / 01 / 2014$ & $06 / 17 / 2014$ & \\
\hline TMG $1288 \mathrm{RR}$ & $19.5 \mathrm{Bc}$ & $18.5 \mathrm{Bc}$ & $19.9 \mathrm{Bc}$ & $27.1 \mathrm{Aa}$ & 21.2 \\
\hline AS 3810 IPRO & $18.0 \mathrm{Bc}$ & $16.0 \mathrm{Bc}$ & $25.1 \mathrm{Ab}$ & $13.0 \mathrm{Cd}$ & 18.0 \\
\hline CD 2792 RR & $21.5 \mathrm{Ab}$ & $20.0 \mathrm{Ac}$ & $21.9 \mathrm{Ac}$ & $16.9 \mathrm{Bc}$ & 20.0 \\
\hline CD 251RR & $20.5 \mathrm{Bc}$ & $19.0 \mathrm{Bc}$ & $25.6 \mathrm{Aa}$ & $16.8 \mathrm{Cc}$ & 20.4 \\
\hline CD 2737RR & $21.0 \mathrm{Ab}$ & $21.0 \mathrm{Ab}$ & $19.9 \mathrm{Ac}$ & $20.2 \mathrm{Ab}$ & 20.5 \\
\hline SHS 820 IPRO & $24.0 \mathrm{Aa}$ & $21.0 \mathrm{Bb}$ & $18.6 \mathrm{Cc}$ & $17.5 \mathrm{Cc}$ & 20.2 \\
\hline TMG 1180 RR & 15.8 Dd & $21.0 \mathrm{Bb}$ & $23.9 \mathrm{Ab}$ & $18.6 \mathrm{Cb}$ & 19.8 \\
\hline M 8766 RR & $19.5 \mathrm{Bc}$ & $23.5 \mathrm{Aa}$ & $20.1 \mathrm{Bc}$ & $15.3 \mathrm{Cd}$ & 19.6 \\
\hline $5 \times 6-3$ & 13.5 De & $23.0 \mathrm{Ba}$ & $26.0 \mathrm{Aa}$ & $18.9 \mathrm{Cb}$ & 20.3 \\
\hline $5 \times 6-2$ & 19.5 Cc & $22.8 \mathrm{Aa}$ & $26.4 \mathrm{Aa}$ & 17.0 Dc & 21.4 \\
\hline $4 \times 6-12$ & $19.0 \mathrm{Ac}$ & $17.8 \mathrm{Ac}$ & $18.9 \mathrm{Ac}$ & $15.1 \mathrm{Bd}$ & 17.7 \\
\hline $4 \times 6-19$ & $17.0 \mathrm{Bd}$ & $18.0 \mathrm{Bc}$ & $20.6 \mathrm{Ac}$ & $20.2 \mathrm{Ab}$ & 18.9 \\
\hline $5 \times 6-1$ & $20.0 \mathrm{Ac}$ & $17.5 \mathrm{Bc}$ & $20.5 \mathrm{Ac}$ & $14.0 \mathrm{Cd}$ & 18.0 \\
\hline $4 \times 6-17$ & $19.5 \mathrm{Bc}$ & $17.0 \mathrm{Cc}$ & $28.1 \mathrm{Aa}$ & 13.8 Dd & 19.6 \\
\hline $4 \times 5-2$ & $20.0 \mathrm{Bc}$ & $23.0 \mathrm{Aa}$ & $22.1 \mathrm{Ac}$ & $19.7 \mathrm{Bb}$ & 21.2 \\
\hline P 98Y70RR & $18.5 \mathrm{Bc}$ & $18.5 \mathrm{Bc}$ & $23.7 \mathrm{Ab}$ & $18.6 \mathrm{Bb}$ & 19.8 \\
\hline M 9144 RR & $20.5 \mathrm{Bc}$ & $18.5 \mathrm{Bc}$ & $23.8 \mathrm{Ab}$ & $13.2 \mathrm{Cd}$ & 19.0 \\
\hline Mean & $19.2 \mathrm{~B}$ & $19.8 \mathrm{~B}$ & $22.7 \mathrm{~A}$ & $17.4 \mathrm{~B}$ & 19.7 \\
\hline Ambient & $-0.54 \mathrm{D}$ & $0.06 \mathrm{~F}$ & $2.96 \mathrm{~F}$ & $-2.34 \mathrm{D}$ & \\
\hline
\end{tabular}

Means followed by the same uppercase letter in the row and by the same lowercase letter in the column constitute a statistically homogenous group by the Scott \& Knott test. F: Favorable D: unfavorable

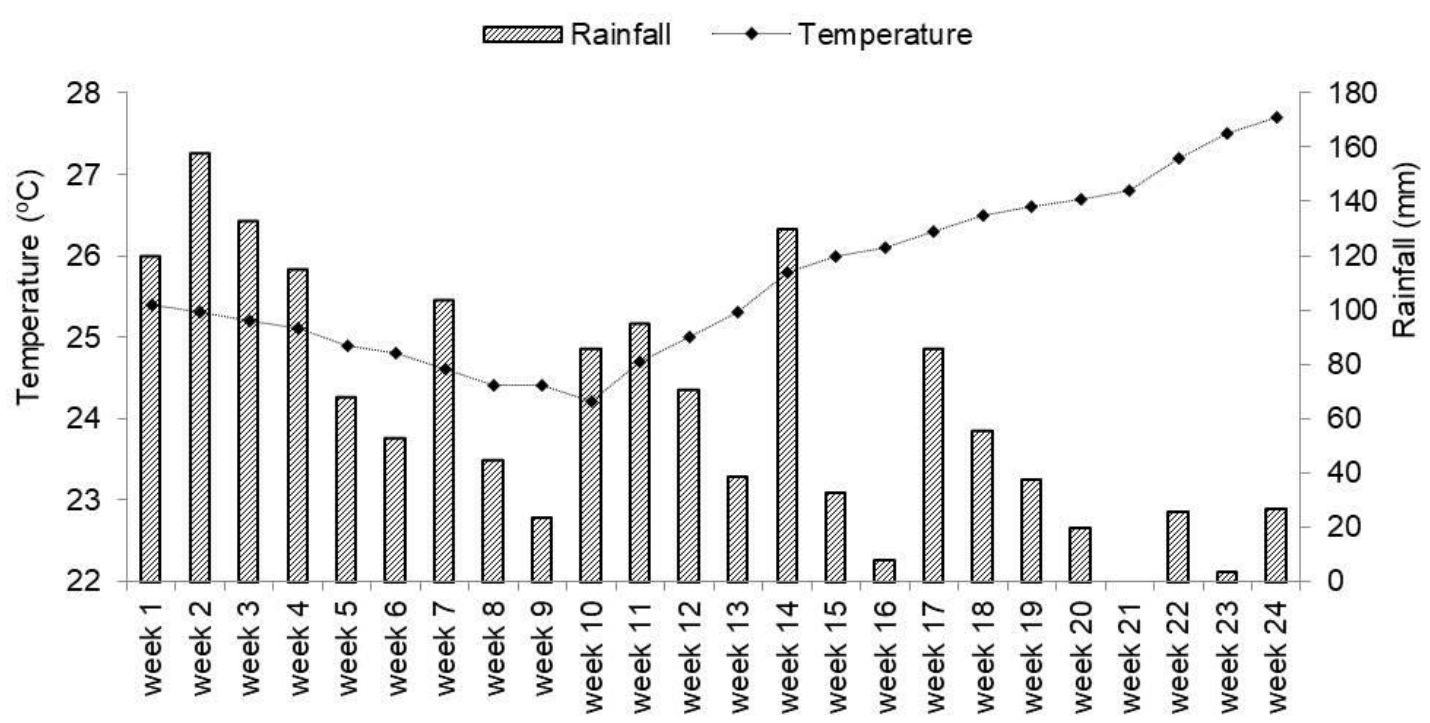

Figure 1 - Temperature and rainfall averages from December 2013 to May 2014 in Palmas-TO.

In the off-season in Gurupi (06/01), three groups of means were formed. Genotype 4X6-17 $(28.1 \%)$ showed the highest value of oil content, although not differing statistically from CD 251RR, 5X6-3 and 5X6-2. The lowest oil contents were from TMG 1288 RR, CD 2792 RR, CD 2737RR, SHS 820 IPRO, M 8766 RR, 4X6-12, 4X6-19, 5X6-1 and 4X5-2.

In the second sowing in Gurupi (06/17), four groups of means were formed. The group with the highest mean was composed by genotype TMG 1288 RR (27.1\%). Genotypes AS 3810 IPRO, M 8766 RR, 4X6-12, 5X6-1, 4X6-17 and M 9144 RR represented the group with the lowest mean. The comparative study between the two sowing times showed that genotypes M 8766 RR, 4X6-12 and 5X6-1 presented the lowest values of oil in both times.

Regarding the mean of off-season trials, the oil content of genotypes whose sowing was performed on June $1^{\text {st }}$ was higher than that of genotypes whose sowing occurred on June $17^{\text {th }}$. This fact may have occurred due to the increase in the average temperature of the environment, reaching almost $30^{\circ} \mathrm{C}$ in some weeks (Figure 2), during the reproductive phase of the crop. In the off-season, due to rainfall scarcity, supplementary sprinkler irrigation was performed to supply the crop's demand for water. 


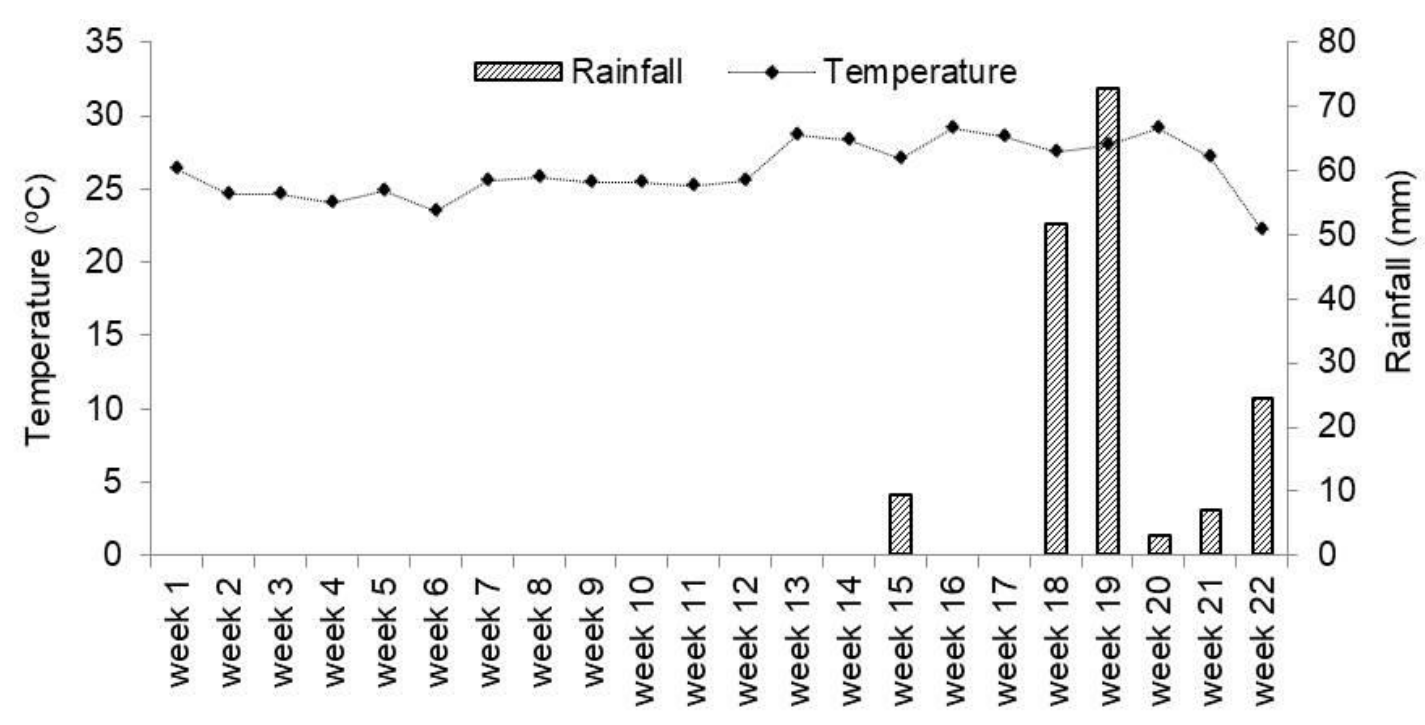

Figure 2 - Temperature and rainfall averages from June to October 2014 in Gurupi-TO.

Oil accumulation in soybean seeds tends to be natural as the average temperature increases (Finoto et al. 2017, Albrecht et al. 2008; Minuzzi et al. 2009). Souza et al. (2013) and Fietz \& Rangel (2008) also verified isolated and/or associated effect of low water availability and high temperatures for this trait.

Ecophysiologically, environmental factors can become stressors when they do not meet the needs of plants satisfactorily or when they reach levels deleterious to the biochemical and physiological activity of the plant (Albrecht et al., 2008).

Kelling \& Fixen (1992) report the effect of high temperatures, associated or not with water stress, on the alteration of metabolic pathways in plants. In these conditions, increased lipid content and decreased protein content are associated with the synthesis of heat shock proteins, such as chaperones. These proteins signal gene expression for the destruction of incorrectly folded proteins, preventing cell death. Furthermore, the increase of lipids in the cell membrane would hinder plant dehydration.

For protein content (Table 4), three statistically distinct groups were formed in the first sowing time (12/01), where genotypes 5X6-3 and 4X6-17 represented the group formed by the highest means (42.0 and $40.0 \%$ respectively). Within the group with the lowest values are TMG 1288 RR, AS 3810 IPRO, CD 2792 RR, CD 2737RR, SHS 820 IPRO, TMG 1180 RR, M 8766 RR and 4X5-2. The other genotypes are in statistically intermediate groups.

In the environment corresponding to the second sowing time (12/17) in Palmas, the genotype that stood out was 4 X6-12, with $37 \%$ protein. Nevertheless, it was statistically superior only to six genotypes, SHS 820 IPRO, 5X6-3, 5X6-2, 4X6-19, 4X5-2 and P 98Y70RR. Genotype 4X6-17 was among the superiors in the two sowing times, making it a possibility for those seeking a material with a high protein content to be planted in the in-season period.

In the off-season period in Gurupi (06/01), genotypes with higher protein content were $4 \times 6-12$ and CD 251RR, with 38.3 and $36.4 \%$, respectively. A statistically lower group was formed, composed of AS 3810 IPRO, CD 2737RR, SHS 820 IPRO, TMG 1180 RR, 5X6-2, 4X6-19, 5X6-1, 4X6-17, 4X5-2 and M 9144 RR.

For the sowing of $06 / 17$ in Gurupi, four groups of means were formed, where genotype AS 3810 IPRO showed the highest protein content $(42.76 \%)$, followed by genotypes 4X6-19 (38.4\%), CD 2737 RR (36.5\%) and CD 251 RR (36.3\%).

The formation of statistically distinct groups between the in-season environments in Palmas and between the off-season environments in Gurupi probably occurred due to the oscillations of the temperatures to which the genotypes were submitted to in each sowing time (Figures 1 and 2). In the two sowing times of the in-season (rainy) period in Palmas, there was a good rainfall distribution during the grain-filling stage (Figure 1).

High temperatures negatively affect biological nitrogen fixation, due to a reduction in the number of root nodules in the reproductive phase of the plant, which coincides with the time of high demand of nitrogen compounds. Thus, this reduction would result in a decrease in the protein content of the grains and an increase in oil contents (Albrecht et al., 2008), since there is a negative correlation between them (Finoto et al., 2017).

High temperatures, mainly associated with periods of low rainfall during maturation, can cause "forced" maturation. Under these conditions, low-vigor seeds are produced because the natural deposition of carbohydrates, lipids and proteins is not verified, as there was a reduction in the translocation of photoassimilates to the grains (Fessel et al., 2010). 
Table 4 - Protein content, in percentage, in the seeds of seventeen soybean genotypes, produced in four sowing seasons, in the 2013/14 crop, in Palmas and Gurupi-TO and the definition of environments proposed by Finlay \& Wilkinson (1963).

\begin{tabular}{|c|c|c|c|c|c|}
\hline \multirow{3}{*}{ Genotype } & \multicolumn{4}{|c|}{ Protein content (\%) } & \multirow{3}{*}{ Mean } \\
\hline & \multicolumn{2}{|c|}{ Sowing time - Palmas } & \multicolumn{2}{|c|}{ Sowing time - Gurupi } & \\
\hline & $12 / 01 / 2013$ & $12 / 17 / 2013$ & 06/01/2014 & 06/17/2014 & \\
\hline TMG 1288 RR & $30.0 \mathrm{Bc}$ & $35.1 \mathrm{Aa}$ & $33.6 \mathrm{Ab}$ & $32.8 \mathrm{Ac}$ & 32.8 \\
\hline AS 3810 IPRO & 29.7 Cc & $35.5 \mathrm{Ba}$ & $31.6 \mathrm{Cc}$ & 42.7 Aa & 34.8 \\
\hline CD 2792 RR & $32.7 \mathrm{Ac}$ & $34.0 \mathrm{Aa}$ & $33.5 \mathrm{Ab}$ & $33.5 \mathrm{Ac}$ & 33.4 \\
\hline CD 251RR & $31.2 \mathrm{Bc}$ & $34.5 \mathrm{Aa}$ & $36.4 \mathrm{Aa}$ & $36.3 \mathrm{Ab}$ & 34.6 \\
\hline CD 2737RR & $31.5 \mathrm{Bc}$ & $35.5 \mathrm{Aa}$ & $32.4 \mathrm{Bc}$ & $36.5 \mathrm{Ab}$ & 33.9 \\
\hline SHS 820 IPRO & $29.7 \mathrm{Ac}$ & $27.7 \mathrm{Ab}$ & $29.3 \mathrm{Ac}$ & $30.4 \mathrm{Ad}$ & 29.2 \\
\hline TMG 1180 RR & $30.3 \mathrm{Bc}$ & $34.5 \mathrm{Aa}$ & $28.3 \mathrm{Bc}$ & $27.4 \mathrm{Bd}$ & 30.1 \\
\hline M 8766 RR & $30.0 \mathrm{Bc}$ & $34.5 \mathrm{Aa}$ & $33.4 \mathrm{Ab}$ & $33.5 \mathrm{Ac}$ & 32.8 \\
\hline $5 \times 6-3$ & $42.0 \mathrm{Aa}$ & $30.0 \mathrm{Bb}$ & $33.6 \mathrm{Bb}$ & $32.9 \mathrm{Bc}$ & 34.6 \\
\hline $5 \times 6-2$ & $36.0 \mathrm{Ab}$ & $31.5 \mathrm{Bb}$ & $30.8 \mathrm{Bc}$ & $33.1 \mathrm{Bc}$ & 32.8 \\
\hline $4 \times 6-12$ & $34.5 \mathrm{Bb}$ & $37.0 \mathrm{Aa}$ & $38.3 \mathrm{Aa}$ & $34.2 \mathrm{Bc}$ & 36.0 \\
\hline $4 \times 6-19$ & $35.4 \mathrm{Ab}$ & $31.0 \mathrm{Bb}$ & $32.2 \mathrm{Bc}$ & $38.4 \mathrm{Ab}$ & 34.2 \\
\hline $5 \times 6-1$ & $37.4 \mathrm{Ab}$ & $34.5 \mathrm{Aa}$ & $31.0 \mathrm{Bc}$ & $31.8 \mathrm{Bc}$ & 33.6 \\
\hline $4 \times 6-17$ & $40.0 \mathrm{Aa}$ & $33.5 \mathrm{Ba}$ & $32.4 \mathrm{Bc}$ & $34.4 \mathrm{Bc}$ & 35.0 \\
\hline $4 \times 5-2$ & $33.0 \mathrm{Ac}$ & $31.5 \mathrm{Ab}$ & $28.1 \mathrm{Bc}$ & $28.1 \mathrm{Bd}$ & 30.1 \\
\hline P 98Y70RR & $36.0 \mathrm{Ab}$ & $28.5 \mathrm{Bb}$ & $34.4 \mathrm{Ab}$ & $30.3 \mathrm{Bd}$ & 32.3 \\
\hline M 9144 RR & $37.5 \mathrm{Ab}$ & $36.5 \mathrm{Aa}$ & $30.6 \mathrm{Bc}$ & $33.7 \mathrm{Bc}$ & 34.5 \\
\hline Mean & $33.9 \mathrm{~A}$ & $33.2 \mathrm{~A}$ & $32.3 \mathrm{~A}$ & $33.5 \mathrm{~A}$ & 33.3 \\
\hline Ambient & $0.6 \mathrm{~F}$ & $-0.1 \mathrm{D}$ & $-1.0 \mathrm{D}$ & $0.2 \mathrm{~F}$ & \\
\hline
\end{tabular}

Means followed by the same uppercase letter in the row and by the same lowercase letter in the column constitute $a$ statistically homogenous group by the Scott \& Knott test. F: Favorable D: unfavorable

Noteworthy, regarding the stress found, the differences reveal a differential behavior among genotypes in relation to the metabolic regulation that determines oil and protein synthesis. This metabolic regulation may affect other macromolecules, probably influencing the synthesis of several other compounds, either primary or secondary.

Table 5 shows the environmental efficiency index (EEI) of each genotype. In this study, according to the definition of environments proposed by Finlay \& Wilkinson (1963), for oil content, the environments classified as unfavorable were 12/01, in Palmas, and 06/17, in Gurupi. On the other hand, for protein content, the unfavorable environments were 12/17, in Palmas, and 06/01, in Gurupi (Tables 3 and 4). The other environments, in both locations, were considered favorable.

Regarding oil content, $53 \%$ of genotypes were efficient, with an environmental efficiency index (EEI) above the general mean (0.75). Genotypes TMG 1288 RR, CD 2737RR and SHS 820 IPRO stood out with, respectively, $1.00,0.87$ and 0.90 .

Regarding protein content, $47 \%$ of genotypes presented an EEl above the general mean (higher than 0.95). Again, cultivar TMG $1288 \mathrm{RR}$, along with CD251 RR, TMG 1180 RR, M 8766 RR and 4×6-12 reached values greater than the unity.

For oil and protein contents in the grains, the highest environmental efficiency index came from the good performance of genotypes in unfavorable environments (Tables 2 and 3). Therefore, the index does not reflect the potential of the genotype when grown under favorable conditions. In this sense, for the chemical composition of soybeans, EEl was efficient in identifying superior genotypes only in unfavorable environments. 
Table 5 - Environmental efficiency index (IEA), according to methodology adapted from Fischer et al. (1983) of 17 soybean genotypes for oil and protein content, from four sowing seasons, in the 2013/14 crop.

\begin{tabular}{lcc}
\hline Genotypes & Oil content $(\%)$ & Protein content $(\%)$ \\
\hline TMG 1288 RR & 1.00 & 1.06 \\
AS 3810 IPRO & 0.65 & 0.90 \\
CD 2792 RR & 0.79 & 0.99 \\
CD 251RR & 0.72 & 1.02 \\
CD 2737RR & 0.87 & 0.97 \\
SHS 820 IPRO & 0.90 & 0.92 \\
TMG 1180 RR & 0.66 & 1.06 \\
M 8766 RR & 0.69 & 1.04 \\
5X6-3 & 0.57 & 0.83 \\
5X6-2 & 0.64 & 0.87 \\
4X6-12 & 0.80 & 1.06 \\
4X6-19 & 0.83 & 0.82 \\
5X6-1 & 0.77 & 0.92 \\
4X6-17 & 0.64 & 0.86 \\
4X5-2 & 0.76 & 0.96 \\
P 98Y70RR & 0.76 & 0.92 \\
M 9144 RR & 0.69 & 0.91 \\
\hline Mean & 0.75 & 0.95 \\
\hline
\end{tabular}

\section{Conclusions}

Genotype TMG 1288 RR showed the highest oil and protein contents.

The best sowing time for protein content was the first of the in-season period (12/01). For oil content, in turn, the best sowing time was in the off-season (06/01).

The identification of superior genotypes by the proposed index was effective only for unfavorable environments.

\section{References}

AOAC - Association of Official Analytical Chemists (1975) Official methods of analysis. $12 \mathrm{ed}$., Washington. 1054p.

Albrecht LP, Braccini AL, Ávila MRT, Suzuki LS, Scapim CA, Barbosa MC (2008) Teores de óleo, proteínas e produtividade de soja em função da antecipação da semeadura na região Oeste do Paraná. Bragantia 67(4):865-873.

Barbosa VS, Peluzio JM, Afferri FS, Siqueira GB (2011) Comportamento de cultivares de soja, em diferentes épocas de semeaduras, visando a produção de biocombustível. Revista Ciência Agronômica 42(3):742-749.

Castro LS, Miranda MH, Lima JE (2015) Indicadores sociais de desenvolvimento e a produção de soja: uma análise multivariada nos 150 maiores municípios produtores brasileiros. Revista Brasileira de Gestão e Desenvolvimento Regional 11(1):69-87.
Cruz CD, Regazzi AJ, Carneiro PCS (2004) Modelos biométricos aplicados ao melhoramento genético. 3.ed. UFV. 279p.

Cruz CD (2007) Programa Genes: Aplicativo computacional em genética e estatística. Versão Windows 2007, Viçosa, UFV.

Embrapa - Empresa Brasileira de Pesquisa Agropecuária CNPSo (2010) Tecnologias de Produção de Soja - Região Central do Brasil 2009-2010. 262 p. (Sistemas de Produção/Embrapa Soja, n. 13)

Fehr WR, Caviness RE, Burmood DT, Pennineton JS (1971) Stage of development descriptions for soybeans, Glycine max L. Merrill. Crop Science 11(6):929-931.

Fietz CR, Rangel MAS (2008) Época de semeadura da soja para a região de Dourados- MS, com base na deficiência hídrica e no fotoperíodo. Engenharia Agrícola 28(4):666-672.

Finlay KW, Wilkinson GN (1963) The analysis of adaptation in a plant-breeding programme. Australian Journal of Agricultural Research 14(6):742-754.

Finoto EL, Sediyama T, Albuquerque JAA, Soares MBB, Galli JA, Cordeiro Junior PS, Pedro Henrique Santos de Menezes PHS (2017) Antecipação e retardamento de colheita nos teores de óleo e proteína das sementes de soja, cultivar Valiosa RR. Scientia Agropecuaria 8(2):99-107. 
Fischer KS, Johnson EC, Edmeads GO (1983) Breeding and selection for drought in tropical maize. Centro Internacional de Mejoramiento de Maiz y Trigo, Mexico, DF (Mexico) CIMMYT. 20p.

Fessel AS, Panobianco M, Souza CR, Vieira RD (2010) Teste de condutividade elétrica em sementes de soja armazenadas sob diferentes temperaturas. Bragantia 69(1):207-214.

10.17268/sci.agropecu.2017.02.02.

doi:

Instituto Adolfo Lutz (1985) Normas analíticas do Instituto Adolfo Lutz: Métodos químicos e físicos para análise de alimentos. São Paulo: Instituto Adolfo Lutz, v.1, p. 533 .

Kelling KA, Fixen PE (1992) Soil and nutrient requirements for oat production. In: Marshall $\mathrm{HG}$ \& Sorrells ME (Eds.) Oat science and technology. Madison, American Society of Agronomy, p.165-190.

Martins ECA, Peluzio JM, Oliveira Junior WP, Tsai SM, Navarrete AA, Morais PB (2015) Alterações dos atributos físico-químicos da camada superficial do solo em resposta à agricultura com soja na várzea do Tocantins. Biota Amazônia 5(4):56-62.

Minuzzi A, Rangel MAS, Braccini AL, Scapim CA, Mora F, Robaina AD (2009) Rendimento de teores de óleo e proteínas de quatro cultivares de soja, produzidas em dois locais no estado do Mato Grosso do Sul. Ciência e Agrotecnologia 33(4):80-93.
Peluzio JM, Fidelis RR, Júnior DA, Santos GR, Didonet J (2008) Comportamento de cultivares de soja sob condições de várzea irrigada no sul do estado do Tocantins, entressafra 2005. Bioscience Journal 24(1):75-80.

Peluzio JM, Afférri FS, Monteiro FJF, Melo AV, Pimenta RS (2010) Adaptabilidade e estabilidade de cultivares de soja em várzea irrigada no Tocantins. Revista Ciência Agronômica 41(3): 427-434.

Rodrigues JIS, Arruda KMA, Cruz CD, Piovesan ND, Barros EG, Moreira MA (2013) Associação de marcadores microssatélites com teores de óleo e proteína em soja. Pesquisa Agropecuária Brasileira 48(3):255-262.

Sbardelotto AIG, Leandro GV (2008) Escolha de cultivares de soja com base na composição química dos grãos como perspectiva para maximização dos lucros nas indústrias processadoras. Ciência Rural, 38(3):614-619.

Sediyama T, Pereira MG, Sediyama CS, Gomes JLL (1996) Cultura da soja. 3 reimp., Universidade Federal de Viçosa, Viçosa-MG. I Parte, 96p.

Souza AP, Mota LL, Zamade T, Martin CC, Almeida FT, Paulino J (2013) Classificação Climática e Balanço Hídrico Climatológico no Estado de Mato Grosso. Nativa 1(1):34-43. doi: 10.14583/2318-7670.v01n0107. 